УДК 579.2

doi: $10.31140 /$ j.vestnikib.2019.3(210).4

\title{
II МЕЖДУНАРОДНАЯ КОНФЕРЕНЦИЯ «ЦИАНОПРОКАРИОТЫ/ЦИАНОБАКТЕРИИ: СИСТЕМАТИКА, ЭКОЛОГИЯ, РАСПРОСТРАНЕНИЕ»
}

\author{
Е.Н. Патова \\ Институт биологии Коми научного центра Уральского отделения Российской академии наук, Сыктывкар \\ E-mail: patova@ib.komisc.ru
}

\begin{abstract}
Аннотация. C 16 по 21 сентября 2019 г. в г. Сыктывкаре (Республика Коми) состоялась II Международная конференция «Цианопрокариоты/цианобактерии: систематика, экология, распространение». Инициатор ее проведения - Институт биологии Коми НЦ УрО РАН. Соучредителями выступили Коми отделение Русского ботанического общества, Коми отделение Общества физиологов растений России. Конференция поддержана грантом Российского фонда фундаментальных исследований № 19-04-20031.
\end{abstract}

Ключевые слова: цианопрокариоты, цианобактерии, «цветение» воды

Научное мероприятие, посвященное обсуждению различных аспектов исследования цианопрокариот, стало продолжением I Международной научной школы-конференции «Цианопрокариоты/цианобактерии: систематика, экология, распространение», которая состоялась в Полярно-альпийском ботаническом саду-институте им. Н.А. Аврорина Кольского НЦ РАН (г. Кировск, 5-9 сентября 2016 г.). Широта охвата научных направлений возросла по сравнению с первой конференцией. Конференция подтвердила актуальность обсуждаемых проблем и необходимость регулярно обмениваться опытом для специалистов, изучающих цианобактерии в самых различных аспектах.

Цианобактерии - прокариотные организмы, обладающие способностью к оксигенному фотосинтезу и фиксации молекулярного азота, что определяет их особое место в системе органического мира, природных комплексах и эволюции биосферы Земли. Представители этой группы микроорганизмов широко распространены в пресных и морских водах, а также в наземных условиях самых разных природных ландшафтов, включая экстремальные, арктические и техногенные местообитания. Многие из них являются продуцентами токсинов и биологически активных веществ.

На конференции рассмотрен широкий круг вопросов, относящихся к исследованиям цианобактерий с применением альгологических и микробиологических подходов. Были заслушаны обзорные и проблемные доклады ведущих специалистов России, стран СНГ и дальнего зарубежья. Работа научного форума проходила по следующим направлениям: флора, биогеография и экология цианопрокариот/цианобактерий; полифазный подход в систематике; молекулярная экофизиология; метагеномные исследования различных сообществ с участием цианопрокариот/цианобактерий; вторичные метаболиты: структура, биосинтез, физиологическая функция, значение в природе, способы обнаружения, биотехнологическое применение; экологические и социальноэкономические проблемы, связанные с массовым развитием цианобактерий в водных экосистемах; цианопрокариоты/цианобактерии в природных сообществах водных и наземных экосистем; симбиотические ассоциации; роль цианобактерий в эволюции биосферы; современные подходы и методы сбора и культивирования цианобактерий.

На пленарной сессии ведущие специалисты в области изучения цианобактерий представили обобщающие и дискуссионные доклады. Д.А. Лось (Институт физиологии растений им. К.А. Тимирязева РАН, г. Москва, Россия) с соавторами (К.С. Миронов, М.А. Синетова) акцентировал внимание на молекулярных триггерах стрессовых ответов у цианобактерий и перспективах их исследований. О.А. Кокшарова (Московский государственный университет имени М.В. Ломоносова, г. Москва, Россия) проанализировала историю вопроса и современное состояние изученности функций вторичных метаболитов цианобактерий. Д.А. Давыдов (Полярно-альпийский ботанический сад-институт им. Н.А. Аврорина Кольского НЦ РАН, г. Апатиты, Россия) от коллектива авторов (Е.Н. Патова, С.С. Шалыгин, А.А. Вильнет, И.В. Новаковская) сообщил о проблемах скрытого разнообразия цианопрокариот арктических территорий. Singh Yadvinder (Университет Шри Гуру Грант Сахиб, Пенджаб, Индия) представил результаты многолетнего изучения разнообразия цианобактерий в горячих источниках и холодных пустынях Северо-Восточных Гималаев. С.А. Садогурская (Никитский ботанический сад - Национальный научный центр РАН, г. Ялта, Россия) подвела итоги исследований разнообразия цианопрокариот эпилитона супралиторали побережья Крымского п-ова, проведенных совместно с Т.В. Белич и С.Е. Садогурским. В докладе, подготовленном Е.Н. Патовой и М.Д. Сивковым (Институт биологии Коми НЦ УрО РАН, г. Сыктывкар, Россия), были рассмотрены особенности функционирования бриофитных ассоциаций азотфиксирующих цианобактерий бореальных болот средней тайги. С.С. Баринова (Институт Эволюции, Университет Хайфы, Хайфа, Израиль) привела классификацию экологических 
группировок цианобактерий и макроклиматических факторов, влияющих на их распространение. В рамках пленарной сессии заслушан оналайндоклад Л.Г. Корневой (Институт биологии внутренних вод им. И.Д. Папанина РАН, пос. Борок, Россия) о результатах изучения состава и экологии цианобактерий в водохранилищах Волго-Донского бассейна. На семинаре по повышению эффективности обработки данных при экологических исследованиях представлен доклад А.Б. Новаковского (Институт биологии Коми НЦ УрО РАН, г. Сыктывкар, Россия) и проведена презентация его авторской программы EXSTATR, используемой для статистической обработки данных в экологии.

На заседаниях секции «Молекулярная экофизиология. Метагеномные исследования различных сообществ с участием цианопрокариот/цианобактерий. Полифазный подход в систематике цианобактерий » были заслушаны два пленарных доклада: о потенциальном участии наружных карбоангидраз цианобактерий в $\mathrm{CO}_{2}$-концентрирующем механизме (Е.В. Куприянова, М.А. Синетова, К.С. Миронов и др.; Институт физиологии растений им. К.А. Тимирязева РАН, г. Москва, Россия) и дистанционное онлайн сообщение об использовании мегафилогении в систематике цианобактерий (C.C. Шалыгин; Центр прибрежных исследований, Техасский университет А \& M, Корпус-Кристи, Техас, США). В секционных сообщениях рассмотрены различные аспекты изучения функциональных характеристик цианобактерий: экофизиологическая характеристика штаммов рода Суanobacterium (М.А. Синетова, А.Ю. Стариков, А.Г. Маркелова и др.; Институт физиологии растений им. К.А. Тимирязева РАН, Московский государственный университет им. М.В. Ломоносова, г. Москва, Россия); цианопрокариоты как компонент лишайников рода Peltigera (Г.Н. Табаленкова, О.В. Дымова, Т.К. Головко;

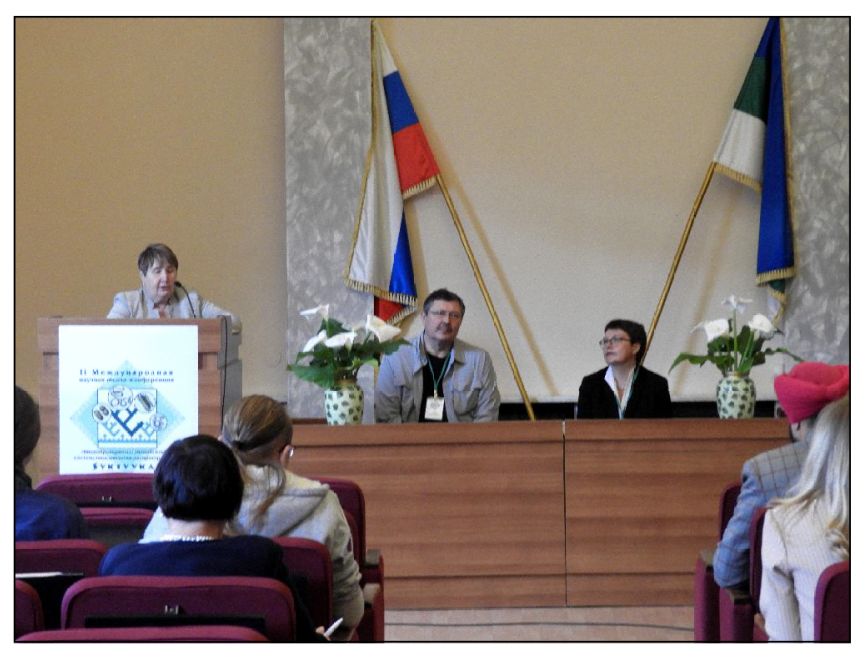

Открытие конференции. С приветственным словом к участникам конференции обращается и.о. директора Института биологии д.б.н. С.В. Дёгтева.
Институт биологии Коми НЦ УрО РАН, Сыктывкар, Россия); новые представители цианобактерий с пигментами, поглощающими дальний красный свет (Е.В. Сенатская, С.Г. Аверина, А.В. Пиневич; Санкт-Петербургский государственный университет, г. Санкт-Петербург, Россия).

Вторую секцию «Вторичные метаболиты: структура, биосинтез, физиологическая функция, значение в природе, способы обнаружения. Цианобактериальные «цветения» в водных экосистемах» открыл пленарный доклад Е.Ю. Воякиной, Я.В. Русских, Е.Н. Черновой, З.А. ЗЖаковской (Санкт-Петербургский научно-исследовательский центр экологической безопасности РАН (НИЦЭБ PАН), г. Санкт-Петербург, Россия) «Распространение цианобактерий и их метаболитов в озерах северо-запада РФ». Разнообразие токсин-продуцирующих цианобактерий в оз. Байкал и водоемaх байкальского региона проанализировано в пленарном докладе О.И. Белых, И.В. Тихоновой, А.В. Кузьмина, А.В. Галкина и др. (Лимнологический институт CO PAH, г. Иркутск; Стайлаб, г. Москва, Россия). Оценка экологической роли цианобактериальных токсинов (микроцистинов) в водных экосистемах приведена в пленарном докладе С.И. Сиделева и А.С. Семеновой (Ярославский государственный университет им. П.Г. Демидова, г. Ярославль, Атлантический филиал ФГБНУ «ВНИРО» ( ААтлантНИРО»), г. Калининград, Россия). В секционных выступлениях были освещены вопросы использования нейронных сетей при мониторинге токсичных цианобактериальных «цветений» (Н.Ю. Григорьева, Т.Р. ЖЖангиров и др.; Научно-исследовательский центр экологической безопасности РАН, Санкт-Петербургский государственный университет, г. СанктПетербург, Россия), молекулярно-генетической идентификации токсигенных цианопрокариот в некоторых водоемах г. Москвы (Н.А Мартыненко, Е.С. Гусев, Е.М. Кезля, М.С. Куликовский; Институт физиологии растений им. К.А. Тимирязева РАН, г. Москва, Россия), а также перспективы использования коллекции CALU в исследовании различных аспектов цианобактериальных «цветений» (Д.Д. Снарская, М.С. Емельянова, Л.В. Чистякова и др.; Санкт-Петербургский государственный университет; Зоологический институт РАН, г. Санкт-Петербург, Россия).

На третьей секции «Цианопрокариоты/цианобактерии - в природных сообществах водных и наземных экосистем. Симбиотические ассоциации» были заслушаны два пленарных доклада: о таксономической оценке нового рода цианобактерий, выделенных из почв Курильских островов (Л.А. Гайсина, А. Saraf, P. Singh; Башкирский государственный педагогический университет им. М. Акмуллы, г. Уфа, Россия; Индуистский университет Банарас, Варанаси, Уттар-Прадеш, Индия) и о разнообразии цианобактерий 
почв Гомельского региона (Ю.М. Бачура; Гомельский государственный университет имени Ф. Скорины, г. Гомель, Беларусь). Секционные доклады включали сообщения о результатах изучения разнообразия представителей рода Nostoc в степной зоне Украины (Е.И. Мальцев и др.; Институт физиологии растений им. К.А. Тимирязева РАН, г. Москва, Россия); изолятах гетероцистных цианобактерий в ассоциациях с Marchantia polimorpha (О.Ф. Женавчук, Е.А. Карбышева, Л.Е. Михеева; Московский государственный университет им. М.В. Ломоносова, г. Москва, Россия); развитии токсичного вида Microcoleus autumnalis в биопленках оз. Байкал (И.В. Тихонова, О.А. Тимошкин, Е.Г. Сороковикова, А.В. Кузьмин и др.; Лимнологический институт СО РАН, г. Иркутск, Россия); изучении биоразнообразия цианобактерий вулканических грунтов и почв Курило-Камчатского вулканического пояса (Р.3. Аллагуватова, Ш.Р. Абдуллин; ФНЦ Биоразнообразия ДВО РАН, г. Владивосток, Россия); коллекции цианобактерий Гербария Вильнюского университета (R. Briskaite, M. Rasimavicius Vilnius University, Institute of Biosciences, Vilnius, Lithuania); роли цианобактерий в фиксации азо'а в содовых озерах Кулундинской стени (О.С. Самылина, З.Б. Намсараев, Т.П. Турова; Институт микробиологии им. С.Н. Виноградского, ФИЦ Биотехнологии РАН, г. Москва, Россия).

Четвертая секция «Роль цианобактерий в эволюции биосферы» включала один пленарный и пять секционных докладов. В пленарном докладе М.M. Астафьевой (Палеонтологический институт им. А.А. Борисяка РАН, г. Москва, Россия) дан обзор развития древнейших ископаемых цианобактерий. В секционных докладах были рассмотрены следующие темы: биогенное происхождение фосфоритов и роль цианобактерий в их образовании (Е.А. Жегалло; Палеонтологический институт им. А.А. Борисяка РАН, г. Москва, Россия); известковые цианобактерии и кальцимикробы в верхнем девоне и нижнем карбоне восточного склона Среднего Урала (С.А. Дуб, О.Ю. Мельничук; Институт геологии и геохимии УрО PAH, г. Екатеринбург, Россия); биокристаллогенезис в цианофитах из водных систем европейского Севера (В.И. Каткова, Т.П. Митюшева; Институт геологии Коми НЦ УрО РАН, г. Сыктывкар, Россия); строматолиты - индикаторы биогеологических событий в раннем палеозое (Тимано-Североуральский регион) (В.А. Матвеев; Институт геологии Коми НЦ УрО РАН, г. Сыктывкар, Россия); тромболиты и строматолиты лагуны де Лос-Сиснес (Чилийская Патагония) (Л.В. Зайцева; Палеонтологический институт им. А.А. Борисяка РАН, г. Москва, Россия).

Заседание пятой секции «Флора, биогеография и экология цианопрокариот/цианобактерий» открыл пленарный доклад З.Б. Намсараева (Нацио- нальный исследовательский центр «Курчатовский институт», г. Москва, Россия), обобщающий сведения об экологических и социально-экономических эффектах, связанных с массовым развитием фототрофных микроорганизмов в водоемах России. В секционных докладах были рассмотрены следующие темы: особенности формирования водорослевых сообществ водоемов оазиса Ширмахера, Восточная Антарктида (С.В. Смирнова; Ботанический институт им. В.Л. Комарова РАН, г. Санкт-Петербург, Россия); структура и пространственная организация цианобактериальных сообществ оазиса Бангера (Антарктида) (Ф.В. Сапожников, О.Ю. Калинина; Институт океанологии им. П.П. Ширшова; Московский государственный университет им. М.В. Ломоносова, г. Москва, Россия); изменение альгоценозов в зоне влияния магистрального газопровода (Большеземельская тундра, Полярный Урал) (Л.Н. Тикушева, Е.Н. Патова; Институт биологии Коми НЦ УрО РАН, г. Сыктывкар, Россия); влияние основных экологических факторов на видовое разнообразие цианопрокариот и водорослей в наземных экосистемах Северного Урала (И.В. Новаковская, Е.Н. Патова, А.Б. Новаковский и др.; Институ' биологии Коми НЦ УрО РАН, г. Сыктывкар, Россия); экологические характеристики цианопрокариот в литобионтных сообществах на поверхности гранитов-рапакиви (О.А. Родина, В.Н. Никитина, Д.Ю. Власов; Санкт-Петербургский государственный университет, г. Санкт-Петербург, Россия). В ряде докладов обсуждены перспективы использования цианобактерий: применение штамма Nostoc paludosum как тест-организма, продуцента биологически активных веществ и сорбента тяжелых металлов (А.И. Фокина, Л.И. Домрачева, С.Г. Скугорева; Вятский государственный университет; Вятская государственная сельскохозяйственная академия, г. Киров, Россия; Институт биологии Коми НЦ УрО РАН, г. Сыктывкар, Россия); влияния цианобактери-

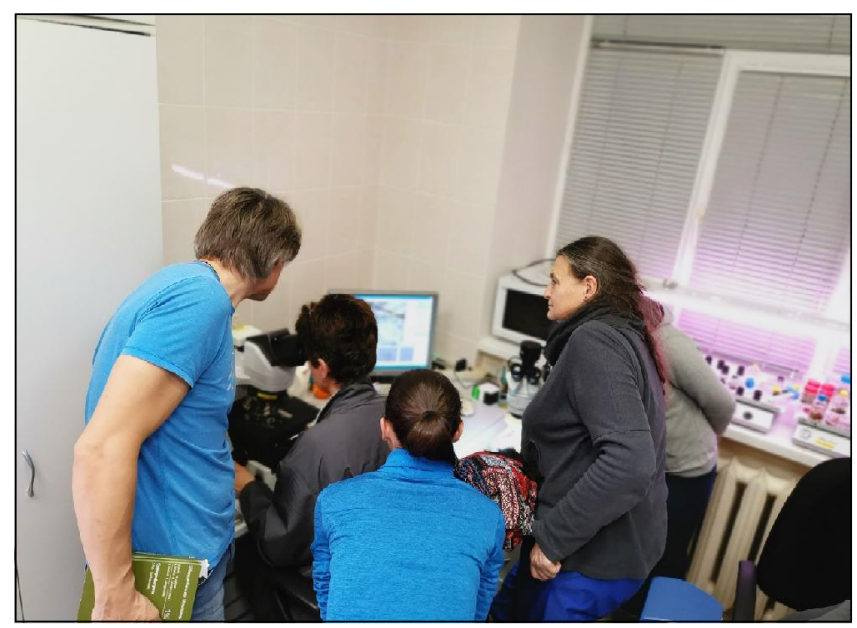

Участники конференции во время работы сессии с микроскопами. 
альной инокуляции на жизнедеятельность растений в условиях химического загрязнения (Е.В. Коваль, С.Ю. Огородникова; Вятский государственный университет, г. Киров). Много докладов данной секции было посвящено вопросам изучения разнообразия цианопрокариот отдельных регионов. О составе цианобактерий Чебоксарского водохранилища и его притоков (Нижегородская область) было рассказано в докладе Е.Л. Воденеевой (соавторы А.Г. Охапкин, П.В. Кулизин, Н.А. Старцева, Е.М. Шарагина; Нижегородский государственный университет им. Н.И. Лобачевского; Нижегородский филиал ФГБНУ «ВНИРО », г. Нижний Новгород, Россия). Особенности развития цианопрокариот в бассейне Нижнего Дона в 2017-2018 гг. рассмотрела Г.Ю. Глущенко (Южный научный центр РАН, г. Ростов-на-Дону, Россия). О цианобактериально-водорослевых сообществах литорали меромиктического оз. Шира (Республика Хакасия, Россия) рассказала Л.А. Гайсина (соавторы А.И. Фазлутдинова, А.О. Бульхин, Д.Ю. Рогозин и др.; Башкирский государственный педагогический университет им. М. Акмуллы, г. Уфа; Институт биофизики СО РАН, г. Красноярск, Сибирский федеральный университет, г. Красноярск). Состав и экологическая характеристика цианопрокариот устьевого участка р. Оки проанализированы в докладе Е.М. Шарагиной (соавторы Е.Л. Воденеева, О.О. Бондарев, А.Г. Охапкин; Нижегородский государственный университет им. Н.И. Лобачевского, г. Нижний Новгород, Россия). Данные о разнообразии Cyanoprokaryota (Cyanobacteria) водоемов Свердловской области (Средний Урал) представлены в докладе Т.В. Еремкиной (Уральский филиал ФГБНУ «ВНИРО ( «УралНИРО»), г. Екатеринбург, Россия). Прозвучал доклад Н.Н. Макарёнковой (Всероссийский научно-исследовательский институт рыбного хозяйства и океанографии, Вологодский филиал, г. Вологда, Россия) о цианопрокариотах малых озер Вожеозерского и Коношско-Верхневажского ландшафтов Вологодской области. Сведения о цианопрокариотах в водоемах бассейна p. Щугор (Приполярный и Северный

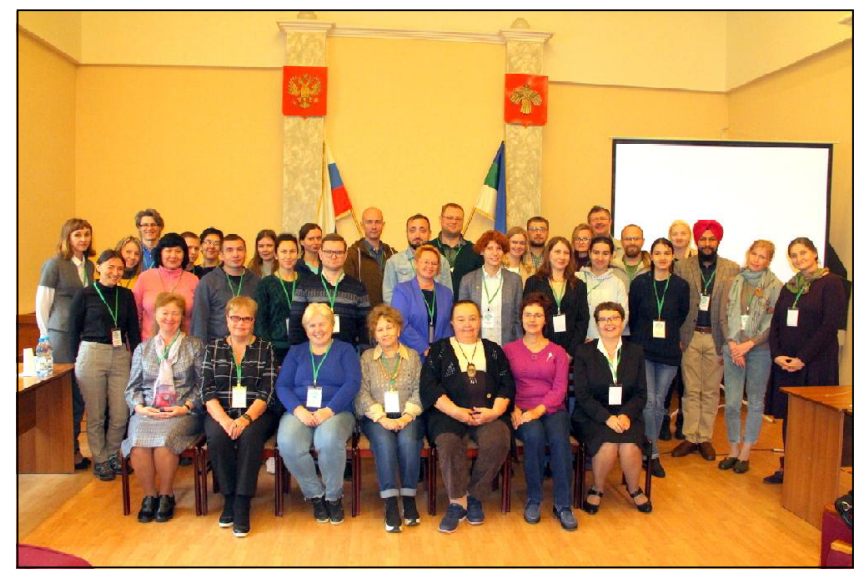

Участники конференции.
Урал) проанализированы и представлены И.Н. Стерляговой (Институт биологии Коми НЦ УрО PAН, г. Сыктывкар, Россия). О флоре Cyanoprokaryota Тазовской губы (Западная Сибирь) рассказала Л.А. Семенова (соавтор М.И. Ярушина; Тюменский филиал ФГБНУ «ВНИРО» («Госрыбцентр»), г. Тюмень, Россия; Институт экологии растений и животных УрО РАН, г. Екатеринбург, Россия). Отдельные экологические группы цианопрокариот рассмотрены в докладах К.К. Горина и Р.Н. Беляковой (Ботанический институт им. В.Л. Комарова РАН, г. Санкт-Петербург, Россия), которые представили предварительные данные о бентосных Cyanoprokaryota восточной части Финского залива Балтийского моря, а также в докладе О.В. Анисимовой и Е.Н. Патовой (Московский государственный университет им. М.В. Ломоносова, Звенигородская биологическая станция, г. Москва; Институт биологии Коми НЦ УрО РАН, г. Сыктывкар, Россия), в котором рассмотрены особенности формирования группы азотфиксирующих цианопрокариот в лесном заболоченном озере (район Кандалакшского залива).

В рамках конференции проведена школа для молодых специалистов с целью теоретического и шрак'тического ознакомления с современными методами исследования цианобактерий, обмена оригинальными методическими разработками при проведении полевых и лабораторных исследований, демонстрации возможностей современных полевых приборов для изучения экологических параметров водной и наземной среды. Организованы полевые әкскурсии (выезды в болотные и лесные комплексы средней тайги для демонстрации методов сбора цианобактерий), сессии с микроскопами с анализом проб, собранных во время экскурсий и привезенных участниками конференции. В рамках работы секции «Роль цианобактерий в эволюции биосферы" Геологическим музеем Института геологии Коми НЦ УрО РАН для участников конференции была организована экспозиция строматолитов. Состоялся обмен научной литературой, электронными версиями актуальных определителей цианопрокариот.

Участниками конференции были приняты следующие решения:

1) продолжить инвентаризацию и изучение разнообразия цианобактерий с использованием молекулярно-генетического анализа (полифазного подхода, включающего комплексное изучение морфологии, физиологии и генетики цианобактерий);

2) развивать исследования представителей этой группы прокариот с позиций современной биологии, экологии, биотехнологии и биомедицины;

3) расширить сотруднитество и координацию исследований, обмен научной информацией и коллекционными образцами между отечественными и зарубежными специалистами; 
4) усилить подготовку молодых специалистов альгологов и микробиологов, занимающихся изучением цианобактерий, через магистратуру, аспирантуру, докторантуру, стажировки в ведущих отечественных и зарубежных центрах;

5) инициировать подготовку программ комплексных исследований цианобактерий, подачу заявок на финансирование совместных научных работ, участие в международных проектах;

6) особое внимание уделить проблеме «цветения» воды токсичными цианобактериями в континентальных водоемах, в том числе в оз. Байкал, и краевых морях России;

7) активно сотрудничать с местными сообществами, органами государственной власти и бизнесом с целью диагностики, ранней профилактики и предотвращения явлений массового развития цианобактерий в водоемах России и связанных с этим экологических и социально-экономических проблем;

8) развивать изучение прикладного использования цианобактерий в сельском хозяйстве, биотехнологиях и т.п.;

9) одобрить привлечение специалистов по бактериальной палеонтологии к работе конференции, рекомендова'ь в дальнейшем выдели'ь секцию по ископаемым цианобактериям, их роли в образовании осадочных пород и эволюции биосферы;

10) подготовить информацию о конференции и направить ее для публикации в профильные научные журналы (Ботанический журнал, Теоретическая и прикладная экология, Альгология,
Вестник Института биологии Коми НЦ УрО РАН); стимулировать публикации обсужденных докладов в региональных и международных изданиях;

11) отметить необходимость проведения школсеминаров (в том числе интерактивных) для молодых специалистов. Рекомендовать проведение в рамках следующей школы-конференции (до начала работы заседаний) двух-трехдневного полевого курса для молодых исследователей по сбору и определению цианопрокариот;

12) посвящать последующие школы-конференции юбилейным (мемориальным) датам ведущих специалистов, внесших значительный вклад в развитие исследований цианобактерий;

13) одобрить инициативу проведения III Международной школы-конференции «Цианопрокариоты/цианобактерии: систематика, экология, распространение» в 2021 г. на базе Башкирского государственного педагогического университета им. М. Акмуллы и в последующем регулярно проводить ее с периодичностью один раз в три года.

Участники конференции выражают признательность фонду РФФИ за поддержку в организации конференции и благодарны Институ'ту биологии Коми НЦ УрО РАН за высокий уровень организации конференции, теплую дружественную атмосферу, обеспечение высокого уровня информированности участников с использованием современных технологий и Интернета, великолепную культурную программу.

\title{
II INTERNATIONAL SCIENTIFIC CONFERENCE «CYANOPROKARYOTA/CYANOBACTERIA: SYSTEMATIC, ECOLOGY, DISTRIBUTION»
}

\author{
E.N. Patova \\ Institute of Biology of Komi Scientific Centre of the Ural Branch of the Russian Academy of Sciences, Syktyvkar
}

Summary. II International scientific Conference «Cyanoprokaryota/Cyanobacteria: systematic, ecology, distribution» was held in September 16-21, 2019 in the Syktyvkar (Komi Republic). The Conference was organized by the Institute of Biology Komi SC UrB RAS with the help of Komi branch of Russian botanical society and Komi Branch of Russian Society of Plant Physiologists, and was supported by Russian Foundation for Basic Research (grant no 19-04-20031).

The conference addressed a wide range of issues related to the study of cyanobacteria using algological and microbiological approaches. Scientists from Russia, CIS countries and far abroad presented reviews and research reports. The main topics of the Conference: Flora, biogeography and ecology of cyanoprokaryota; Polyphasic approach in systematics; Molecular ecophysiology; Metagenomic studies of various communities involving Cyanoprokaryota/Cyanobacteria; Secondary metabolites: structure, biosynthesis, physiological function, importance for nature, methods of detection, biotechnological applications; Cyanobacterial «blooms» in aquatic ecosystems, the development of techniques and methods for the ecological rehabilitation of water bodies; Cyanoprokaryota/Cyanobacteria in the natural communities of aquatic and terrestrial ecosystems. Symbiotic associations; The role of cyanobacteria in the evolution of the biosphere; Modern approaches of sampling and cultivation.

Key words: cyanoprokaryota, cyanobacteria, «bloom» of water 